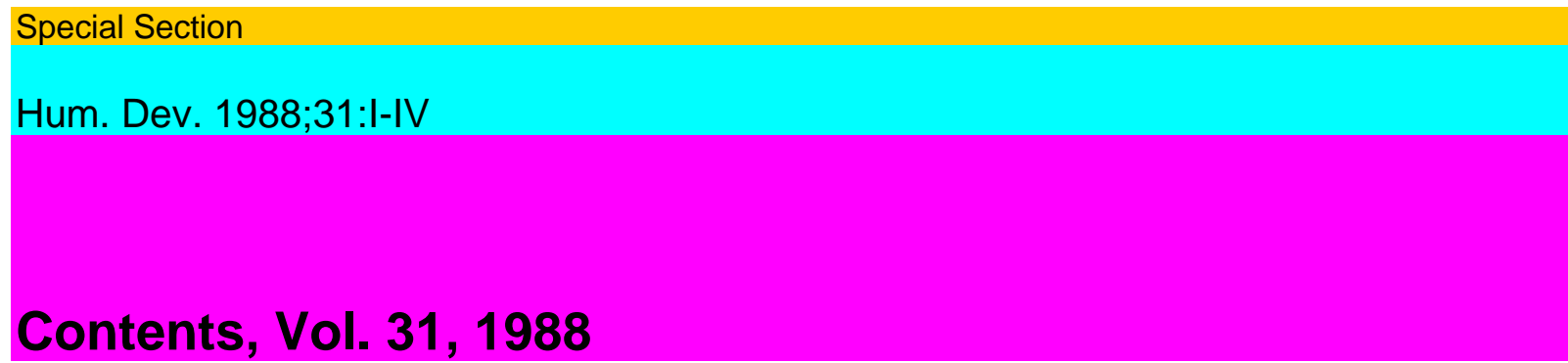

\title{
Contents Vol. 31,1988
}

No. 1 Editorial Statement

Kuhn, D 1

Special Topic: Concepts and Categorization

Where Do Taxonomic Categories Come from?

Nelson, K 3

Dynamic Concepts and Functionality: The Influence of Multiple Representations and

Environmental Constraints of Categorization

Richards, D.D 11

On the Linguistic Origin of Superordinate Categorization

Benelli, B 20

Children's Expectations Concerning Natural Kind Categories

Gelman, S.A 28

Commentary: Conceptual Heterogeneity versus Developmental Homogeneity (on

Chairs and Bears and Other Such Pairs)

Keil, F.C $\quad 35$

Papers

Implications of Cultural Diversity for the Universality Claims of Kohlberg's Theory of

Moral Reasoning

Boyes, M.C.; Walker, L.J 44

Ships in the Night: Piaget and American Cognitive Science

Brown, $\mathrm{T}$

60

No. 2 Original Paper

Psychological Individualism: Gender Differences or Gender Neutrality

Archer, S.L.; Waterman, A.S 65

Evaluating Piaget's Infancy Books as Works-in-Progress. The Case of Prehension

Gratch, G.; Schatz, J.A 82

Contextuality and Directionality of Cognitive Development

Chapman, M 92

Graph-Theoretical Representation of the Structure of Developmental Models

van Geert, P 107

Announcement 136

111

3 Papers

Cross-Cultural Research in the Sociohistorical Tradition

Cole, M 137

Commentary: Velichovsky, B153

Commentary: Jahoda, G 156

Project and Prejudice: Past, Present, and Future in Adult Development 
Robinson, R.E 158

Commentary: Gardner, H 173

The History of Child Psychology as Seen through Handbook Analysis

Hooper, F.H 176

Book Review 185

In Memory: Nancy Datan, Lawrence Kohlberg, Joachim F. Wohlwill 188

Announcement 196

4 Papers

Mental Self-Government: A Theory of Intellectual Styles and Their Development

Sternberg, R.J 197

Commentary: Lerner, R.M.; Lerner, J.V 222

Piaget's Category-Theoretic Interpretation of Cognitive Development: A Neglected Contribution

Davidson, P.M 225

Commentary: Beilin, $\mathrm{H} \quad 242$

Another Look at Piaget's Books on Infancy

Gratch, G; Schatz, J.A245

Essay Review 256

5 Papers

Vivid Memories and the Reminiscence Phenomenon: The Role of a Self Narrative

Fitzgerald, J.M 261

Commentary: Neisser, U 271

Piaget on Variation and Selection Models: Structuralism, Logical Necessity, and Interactivism

Bickhard, M.H 274

Relational Processes in Adolescent and Adult Dialogues: Assessing the Intersubjective Con text of Conversation

Leadbeater, B.J 313

Essay Review 327

6 Papers

Vygotsky, Piaget and the Dialectic of Development

Bidell, $\mathrm{T} \quad 329$

Commentary: Rogoff, B 346

IV Contents

Special Topic: Cross-Cultural Studies of Parental Influence on Children's Achievement

Introduction

Stevenson, H.W 349

Cultural Values, Parents' Beliefs, and Children's Achievement in the United States and

China

Chen, C; Uttal, D.H 351

Intergenerational Literacy: Effects of Parental Literacy and Attitudes on Children's Read ing Achievement in Morocco

Wagner, D.A.; Spratt, J.E 359

The Influence of Family Demographics and Parental Teaching Practices on Peruvian Chil dren's Academic Achievement

Barber, B.L 370 
Maternal Expectations, Classroom Experiences, and Achievement among Kindergartners in the United States and Japan

Bacon, W.F.; Ichikawa, V 378

Commentary: Sigel, I.E $\quad 384$

Book Review 391

Acknowledgement 394

Author Index 395

Subject Index $\quad 396$

S. Karger · Medical and Scientific Publishers

Basel · München · Paris · London · New York · New Delhi · Singapore · Tokyo · Sydney

All rights reserved. (c) Copyright 1988 by

No part of this publication may be translated into other $\quad$ S. Karger AG, P.O. Box, CH-4009

Basel (Switzerland)

languages, reproduced or utilized in any form or by any Printed in Switzerland by Thür AG Offsetdruck, Pratteln

means, electronic or mechanical, including photocopying, recording, microcopying, or by any information storage and retrieval system, without permission in writing from the publisher or, in the case of photocopying, direct payment of a specified fee to the Copyright Clearance Center (see 'Information for Readers and Subscribers'). 